\title{
Size at first reproduction of the sea urchin Strongylocentrotus purpuratus in a central California kelp forest
}

\author{
M. C. Kenner*, M. T. Lares** \\ Moss Landing Marine Laboratories, Moss Landing, California 95039-0450, USA
}

\begin{abstract}
A subtidal population of Strongylocentrotus purpuratus limited to small individuals (mostly $\leq 30 \mathrm{~mm}$ test diameter) by sea otter predation was examined to determine the size of reproductive sea urchins. Although a previous study found that most individuals of $S$. purpuratus examined were not reproductively mature until larger than $30 \mathrm{~mm}$ diameter, in this population most individuals $16 \mathrm{~mm}$ and larger were mature. The possible influence of habitat on the size at first reproduction is discussed.
\end{abstract}

Often, due to energetic or mechanical constraints, a predator will only exploit prey of a particular size range. For this reason, prey species may have a size refuge from predation. The refuge may be large body size, such as that which protects the mussel Mytilus californianus and the barnacle Balanus cariosus from predation by the gastropod Thais spp. (Dayton 1971) and $M$. californianus from predation by the sea star Pisaster ochraceus (Paine 1976), or small body size, as is the refuge of Mytilus edulis (VanBlaricom 1988) and several temperate eastern Pacific sea urchin species from predation by the sea otter Enhydra lutris (Estes \& VanBlaricom 1988, Estes et al. 1989).

In habitats lacking suitable spatial refuges, sea otter predation can lead to a complete elimination of the larger size classes of sea urchins (Estes et al. 1978, Kenner in press). This predation could either lead to loss of the reproductive segment of the population, or, because large sea urchins have considerably more reproductive potential than small sea urchins (gonad size is limited by test volume, which is a cubic function of diameter), greatly reduce the population's reproductive output.

Little information is available concerning the size at first reproduction for species of sea urchins in the field. Of those species for which there is information, several show some variation with habitat in the size or age at

\footnotetext{
Present addresses:

- Institute of Marine Sciences, University of California, Santa Cruz, California 95064, USA

- Department of Biology, University of South Florida, Tampa, Florida 33620, USA
}

first reproduction. Strongylocentrotus intermedius was found to become reproductive at a test diameter of 15 to $20 \mathrm{~mm}$ or $2 \mathrm{yr}$ of age in shallow water but not until 30 to $35 \mathrm{~mm}$ or $3 \mathrm{yr}$ in deeper habitats (Kawamura \& Taki 1965, Kawamura 1973). Evechinus chloroticus matured at 35 to $40 \mathrm{~mm}$ test diameter at one location and at 55 to $75 \mathrm{~mm}$ at another with poorer food (Dix 1970). A littoral population of the irregular sea urchin Echinocardium cordatum matured at $3 \mathrm{yr}$ of age and ca $30 \mathrm{~mm}$ test length, whereas a deeper offshore population failed to mature during 7 yr of observation (Buchanan 1966).

Where their distributions overlap, predation by Enhydra lutris can dramatically influence the size distribution of the purple sea urchin Strongylocentrotus purpuratus (Lowry \& Pearse 1973, Kenner in press). Gonor (1972) collected S. purpuratus from intertidal populations in Oregon, USA, outside the present range of the sea otter. He found that at the peak of the reproductive season they were not reproductively mature until above $25 \mathrm{~mm}$ test diameter; only about half the sea urchins examined between 30 and $35 \mathrm{~mm}$ diameter were fertile.

Methods and results. We examined size at reproductive maturity in a subtidal population of Strongylocentrotus purpuratus from Stillwater Cove in Carmel Bay, California $\left(36^{\circ} 34^{\prime} \mathrm{N}, 121^{\circ} 57^{\prime} \mathrm{W}\right)$, where sea otters had been present since 1956 (Ebert 1968). The sea urchins inhabited dense mats of geniculate coralline algae which covered most of the rock substrate (Kenner in press). During most of the 1983 to 1987 period, 90 to $100 \%$ of the sea urchin population consisted of individuals $30 \mathrm{~mm}$ test diameter or less, with rare individuals as large as $40 \mathrm{~mm}$ diameter. Growth rates derived from tetracycline-labeled sea urchins and the movement of size frequency modes over time indicated that most of the population was less than 2 yr old (Kenner in press). However, this population had a distinct synchronized reproductive cycle, with spawning occurring in April and May, as shown by gonad indices $(100 \times$ gonad wet weight/sea urchin 


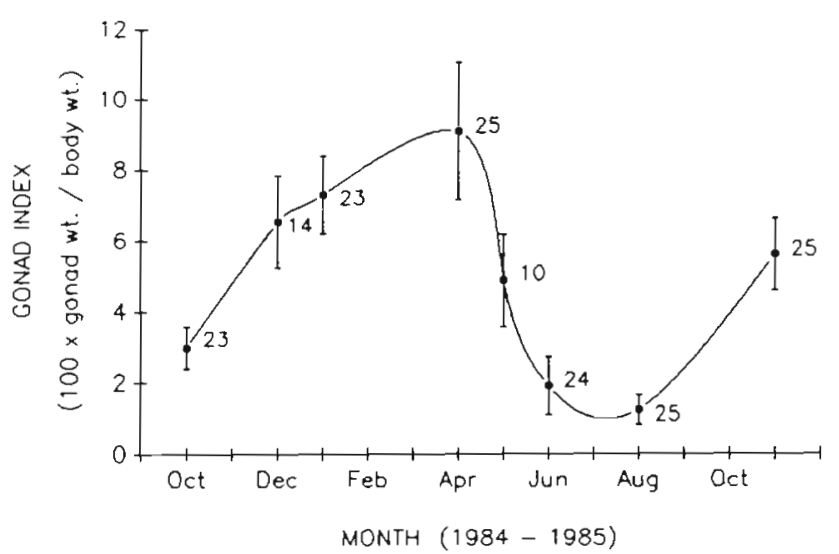

Fig. 1. Strongylocentrotus purpuratus. Seasonal cycle of gonad indices, monitored from October 1984 to November 1985 in Stillwater Cove, California $(\overline{\mathrm{x}} \pm 1 \mathrm{SE} ; \mathrm{n}=10$ to 25 , indicated on figure)

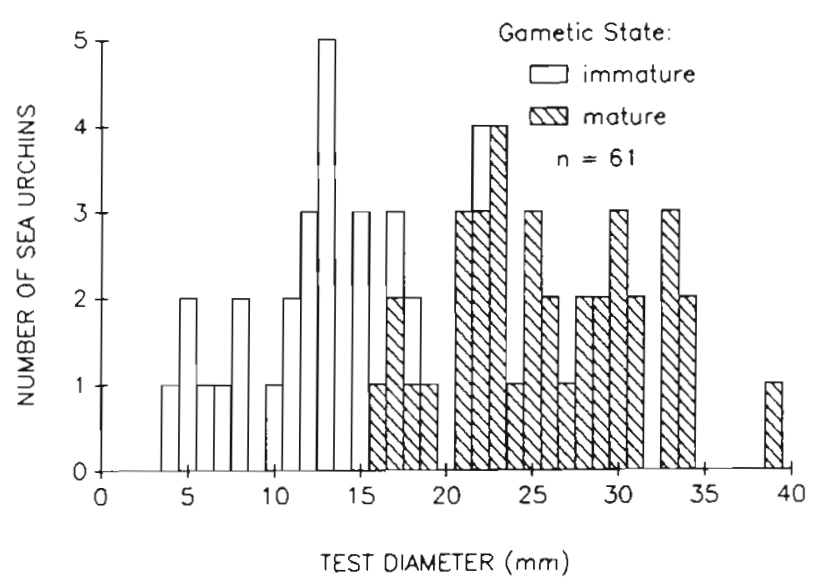

Fig. 2. Strongylocentrotus purpuratus. Size frequency distribution of sea urchins collected March 1987 from Stillwater Cove, California. Hatched bars indicate individuals with viable gametes

wet weight) measured in 1984 to 1985 (Fig. 1). The time of spawning observed here is within the range (January to May) observed in populations from this area (Holland \& Giese 1965).

In March 1987, when gonadal development was predicted to be near its peak (Fig. 1), 61 sea urchins were collected from the Stillwater Cove population using 14 randomly selected $0.25 \mathrm{~m}^{2}$ quadrats. Test diameters in the sample ranged from 4 to $39 \mathrm{~mm}$ (Fig. 2). In the laboratory, sea urchins $10 \mathrm{~mm}$ diameter or larger were dissected and fresh smears of their gonads were examined for the presence of gametes. When gametes were found, they were mixed with gametes from an individual of the opposite sex, as in Gonor (1972). If the fertilization membranes were lifted, both individuals were considered mature. Fertile individuals as small as $16 \mathrm{~mm}$ were found. All sea urchins larger than $22 \mathrm{~mm}, 79 \%$ of those between 16 and 22 $\mathrm{mm}$, and $60 \%$ of the entire sample were fertile (Fig. 2). Females made up $46 \%$ of the fertile individuals, with a minimum diameter of $18 \mathrm{~mm}, 2 \mathrm{~mm}$ larger than the smallest fertile male. No effort was made to sex nonfertile individuals.

Discussion. Estes et al. (1978) suggested that sea otter predation could lead to a shift to smaller reproductive sizes in sea urchins through natural selection. Selective predation on larger sea urchins could result in a fitness advantage to individuals which are able to reproduce at a smaller size. A lower somatic growth rate might also be favored if it increased the opportunity for reproduction before outgrowing the size refuge from predation, and if resources made available by lower growth rates were reallocated to reproduction. This explanation of the smaller size of reproduction observed here could be valid only if the sea urchins in the Stillwater Cove population originated from larvae spawned within the sea otter range. Stillwater Cove is ca $75 \mathrm{~km}$ south of the northern end of the California sea otter's range. Given a planktonic larval period of ca 2 to 3 mo (Strathmann 1978), it is likely that the larvae originated outside the sea otter range.

Alternatively, the smaller size of reproductive maturity observed here could result from environmental factors such as latitude, tidal height, or food availability. Of these factors, only food availability has been shown to affect reproduction in echinoids. Although intertidal populations of Strongylocentrotus intermedius (Kawamura 1973) and Echinocardium cordatum (Buchanan 1966) were found to grow faster and mature at a younger age than subtidal populations, food was thought to be the critical factor in both studies.

It is well documented that the nutritional state of echinoids is reflected in their gonadal development; sea urchins from deforested habitats typically have smaller gonads than those from kelp forests (Pearse 1980). Also, abundant food can yield high gonad indices and small $(15 \mathrm{~mm})$ reproductive Strongylocentrotus purpuratus in the laboratory (Pearse et al. 1986. Pearse pers. comm.) However, Thompson (1982) has shown that $S$. droebachiensis which were given a low food ration preferentially allocated a larger share of their resources to reproduction at the expense of somatic growth. In addition, both Leighton (1967) and Lees (1970) found that small $S$. purpuratus from food-poor habitats had higher gonad indices than similar-sized ones from food-rich habitats. Leighton concluded that this situation resulted from reproduction being tied to age rather than size. Similarly, Dix (1970) found that Evechinus chloroticus from 2 areas with different growth rates matured at about the same age ( 3 or $4 \mathrm{yr}$ ) although their sizes differed.

The diet of the Stillwater Cove population of sea 
urchins consisted largely of geniculate coralline algae (Kenner in press), which laboratory studies have shown support reduced growth rates in Strongylocentrotus purpuratus (North 1964, Boolootian 1966, Leighton 1971, Kenner unpubl. data). Growth rates in this population were found to be lower than previous studies (Ebert 1977, Russell 1987) had found for this species, with a calculated age of 1 yr occurring at a diameter of ca $17 \mathrm{~mm}$ (Kenner in press). Gonor (1973), on the other hand, describes both of his collection sites as having abundant attached algae in summer and ample drift after winter storms, but nothing is said of the sea urchins' demography or diet there. It is possible then that reduced growth due to diet may have led to the observed difference in size of reproduction in these 2 populations.

Regardless of the basis of this relationship between body size and reproductive maturity, the presence of small sea urchins with viable gametes in Stillwater Cove presumably enables the population there to remain reproductive even though it lacks large individuals. This study demonstrates that size at first reproduction may be dependent on habitat. However, if the reproductive demography described here is anomalous, and that found in Oregon populations by Gonor (1972) is more typical, then cracks and crevices sufficient to harbor larger individuals may be necessary in order to maintain the reproductive viability of Strongylocentrotus purpuratus populations in the presence of sea otters.

Acknowledgements. We thank $M$. Foster for providing lab space and encouragement. Diving assistance for the March collection was provided by P. Harper. S. Dearn and a number of other students from Moss Landing Marine Laboratories lent diving assistance for the M.Sc thesis which led to this work. The help of the internship staff of LIU/Southhampton College is also appreciated. Finally, we thank J. Estes, J. Pearse, G. VanBlaricom and 3 anonymous reviewers for their comments on earlier versions of this manuscript.

\section{LITERATURE CITED}

Boolootian, R. A. (1966). Reproductive physiology. In: Boolootian, R.A. (ed.) Physiology of Echinodermata. Interscience Publishers, New York, p. 561-613

Buchanan, J. B. (1966). The biology of Echinocardium cordatum (Echinodermata: Spatangoidea) from different habitats. J. mar. biol. Ass. U.K. 46: 97-114

Dayton, P. K. (1971). Competition, disturbance and community organization: the provision and subsequent utilization of space in a rocky intertidal community. Ecol. Monogr. 41: $351-389$

Dix, T G. (1970). Biology of Evechinus chloroticus (Echinoidea: Echinometridae) from different localities 3. Reproduction. N.Z. J. mar. Freshwat. Res. 4: 385-405

Ebert, E. E. (1968). A food habits study of the southern sea otter, Enhydra lutris nereis. Calif. Fish Game 54: 33-42
Ebert, T. A. (1977). An experimental analysis of sea urchin dynamics and community interactions on a rock jetty. J. exp. mar. Biol. Ecol. 27: 1-22

Estes, J. A., Smith, N. S., Palmisano, J. F. (1978). Sea otter predation and community organization in the western Aleutian Islands, Alaska. Ecology 59: 822-833

Estes, J. A., Duggins, D. O., Rathbun, G. B. (1989). The ecology of extinctions in kelp forest communities. Conserv. Biol. 3: 252-264

Estes, J. A., VanBlaricom, G. R. (1988). Concluding remarks. In: VanBlaricom, G. R., Estes, J. A. (eds.) The community ecology of sea otters. Springer-Verlag, Berlin, p. 210-218

Gonor, J. J. (1972). Gonad growth in the sea urchin Strongylocentrotus purpuratus (Stimpson) (Echinodermata: Echinoidea) and the assumptions of gonad index methods. J. exp. mar. Biol. Ecol. 10: 89-103

Gonor, J. J. (1973). Reproductive cycles in Oregon populations of the echinoid, Strongylocentrotus purpuratus (Stimpson). I. Annual gonad growth and ovarian gametogenic cycles. J. exp. mar. Biol. Ecol. 12: 45-64

Holland, N. D., Giese, A. C. (1965). An autoradiographic investigation of the gonads of the purple sea urchin Strongylocentrotus purpuratus. Biol. Bull. mar. biol. Lab., Woods Hole 128: 241-258

Kawamura, K. (1973). Fishery biological studies on a sea urchin, Strongylocentrotus intermedius (A. Agassiz). Sci. Rep. Hokkaido Fish. Exp. Sta. 16: 1-54

Kawamura, K., Taki, J. (1965). Ecological studies on the sea urchin, Strongylocentrotus intermedius, on the coast of Funadomari in the north region of Rebun Island. III. Sci. Rep. Hokkaido Fish. Exp. Sta. 4: 22-40

Kenner, M. C. (in press). Population dynamics of the sea urchin Strongylocentrotus purpuratus in a central California kelp forest: recruitment, mortality, growth, and diet. Mar. Biol.

Lees, D. C. (1970). The relationship between movement and available food in the sea urchins Strongylocentrotus franciscanus and Strongylocentrotus purpuratus. M.Sc. thesis. San Diego State University

Leighton, D. L. (1967). Ecological investigations of sea urchin populations along the Palos Verdes Peninsula. In: North, W. J. (ed.) Annual. Report, Kelp Habitat Improvement Project 1966 bis 1967. California Institute of Technology, Pasadena, p. $41-54$

Leighton, D. L. (1971). Grazing activities of benthic invertebrates in southern California kelp beds. In: North, W. J. (ed.) The biology of giant kelp beds (Macrocystis) in California. Nova Hedwigia (Suppl.) 32: 421-453

Lowry, L. F., Pearse, J. S. (1973). Abalones and sea urchins in an area inhabited by sea otters. Mar. Biol. 23: 213-219

North, W. J. (1964). An investigation of the effects of discharged wastes on kelp. Pub. 26. The resources agency in California, State Water Quality Control Board, Sacramento

Paine, R. T (1976). Size-limited predation: an observational and experimental approach with the Mytilus-Pisaster interaction. Ecology 57: 858-873

Pearse, J. S. (1980). Synchronization of gametogenesis in the sea urchins Strongylocentrotus purpuratus and S. franciscanus. In: Clark, W. H. Jr, Adams, T. S. (eds.) Advances in invertebrate reproduction. Elsevier North Holland, New York, p. 53-68

Pearse, J. S., Pearse, V. B., Davis, K. K. (1986). Photoperiodic regulation of gametogenesis and growth in the sea urchin Strongylocentrotus purpuratus. J. exp. Zool. 237: $107-118$

Russell, M. P. (1987). Life history traits and resource allocation 
in the purple sea urchin Strongylocentrotus purpuratus (Stimpson). J. exp. mar. Biol. Ecol 108: 199-216

Strathman, R. (1978). Length of pelagic period in echinoderms with feeding larvae from the northeast Pacific. J. exp. mar. Biol. Ecol. 34: 23--27

Thompson, R. J. (1982). The relationship between food ration

This note was submitted to the editor and reproductive effort in the green sea urchin, Strongylocentrotus droebachiensis. Oecologia 56: 50-57

VanBlaricom, G. R. (1988). Effects of foraging by sea otters on mussel-dominated intertidal communities. In: VanBlaricom, G. R., Estes, J. A. (eds.) The community ecology of sea otters. Springer-Verlag, Berlin, p. 48-91

Manuscript first received: January 16, 1991

Revised version accepted: August 13, 1991 